\title{
Real and Accrual Earnings Management around Initial Public Offerings in Jordan
}

\author{
Mohammad M. Alhadab ${ }^{1}$ \\ ${ }^{1}$ Assistant Professor, Department of Accounting, Faculty of Economics and Administrative Sciences, Al al-Bayt \\ University, Jordan
}

Correspondence: Mohammad Alhadab, Department of Accounting, Faculty of Economics and Administrative Sciences, Al al-Bayt University, P.O. Box 130040, Mafraq 25110, Jordan.

Received: December 4, 2017

doi:10.5539/ibr.v11n1p204
Accepted: December 25, 2017 Online Published: December 27, 2017

URL: https://doi.org/10.5539/ibr.v11n1p204

\begin{abstract}
This study examines whether Initial Public Offering (IPO) firms in Jordan utilize real activities and accruals accounting during the offering year to manipulate income. To date the current study is the first to examine real activities and accrual earnings management that undertaken by IPO firms in Jordan. Using a Jordanian sample of 41 IPO firms over the period between 2000 and 2011, this study provides new e vidence to the literature that IPO firms in Jordan utilize real activities and accruals accounting to inflate net income that is reported during the offering year. In particular, the findings of current study show that IPO firms report a higher level of earnings manipulation during the offering year that conducted via accrual-based earnings management, sales-based, discretionary expenses-based, and the aggregated measure-based of real activities.
\end{abstract}

Keywords: initial public offerings, accruals-based earnings management, real activities-based earnings management, Jordan

JEL classification: G14, M41, M41

\section{Introduction}

The Initial Public Offering (IPO) is considered as a very important change in the firm's life cycle where the firm is switched from being a private to a public firm by selling its shares for the first time to the public (interested investors). The investment banks (underwriters) play a significant role by helping the IPO firm to set the offering price and the number of shares to be offered to the public. Interested investors in their turn take into their consideration many factors before investing in an IPO e.g. previous earnings record, disclosure quality, information asymmetry, risk profile, quality of audit firm, etc. Based on a survey with more than 330 financial managers, a study by Brau and Fawcett (2006) has found historical income records are among the most important factors that may affect the IPOs' prices.

Given the importance of income records around IPOs, prior studies have examined the financial reporting quality around the offering year and found IPO firms manipulate income before, during, and after the offering year (e.g., Teoh et al., 1998; Gramlich and Sorensen, 2004; Wongsunwai, 2013; Alhadab, 2015). This research has also pointed that a higher level of information asymmetry between IPO firms' management and potential investors provides managers with more flexibility to manipulate income using different techniques e.g. accrual earnings management, real activities, classification shifting (Teoh et al., 1998; Alhadab et al. 2016).

The majority of prior studies that have examined earnings management around IPOs use samples from developed economies such as US and UK IPOs. For example, Teoh et al. (1998), Fan (2007), Bao et al. (2013), Wongsunwai (2013) and Ertimur et al. (2017) have examined US IPOs and found IPO firms utilize accrual earnings management to inflate reported income. Further, Chahine et al. (2012), Alhadab et al. (2015), Alhadab et al. (2016) have examined earnings management around IPOs in the UK and found IPO firms utilize accrual and real earnings management around IPOs. Roosenboom et al. (2003) have examined Dutch IPO, while Cormiera and Martinezb (2006) have examined French IPOs.

Although prior studies have investigated the association between earnings management and IPOs, very limited studies have explored this association using samples from developing economies. The US and UK markets are very developed markets with very restricted regulatory environments, difficult listing requirements, and strong 
governance mechanism. Thus, it seems generalizing the research findings based on IPOs sample from a developed country to a developing country is inappropriate.

This study attempts to enhance literature on the association between earnings management and IPOs using a sample from a developing economy, namely Jordan. Recent research has examined earnings practices using Jordanian samples and found evidence that Jordanian public firms utilize real activities and accrual-based earnings management to manipulate income upwards (e.g. Abu Jebril and Al.Thuneibat, 2016; Alzoubi, 2016; Alqatamin et al., 2017; Ibrahim and Al Awawdeh, 2017).

Jordan is one of the developing economies that located in the Middle East with total population of 9.5 million and it has just one stock exchange where public firms can be listed, the Amman Stock Exchange (ASE) ${ }^{\text {. The }}$ ASE imposes a very lighter set of regulations to encourage small private companies to go public. However, stock exchanges that impose lighter regulations are expected to have very lighter listing requirements, very week corporate governance, lower level of disclosure system, and lower quality of transparency (Alhadab 2016b; Alhadab et al. 2016). Thus, it is expected the requirements for Jordanian private companies to go public (IPO) are not restricted as compared to other requirements imposed by restricted stock exchanges. All these differences in terms of regulation, corporate governance, listing requirements, disclosure system between the ASE and other developed stock exchanges would for sure provide the managers of IPO firms in Jordan with more flexibility to manage reported earnings. This paper will therefore address this issue by shedding more lights on earnings management activities that undertaken by IPO firm during the offering year.

Recently, Alhadab et al. (2015) examined a sample of British IPOs and found a positive association between bankruptcy risk and the level of earnings management. This evidence suggests that investors would lose their money which invested in an IPO due to management opportunistic behavior. Thus, examining earnings management in developing countries would help the policy makers, regulators and related authorities not to jus $t$ protect investors' wealth, but would help to alleviate the negative consequences of earnings management that may extend to the whole economy.

This study examines 41 Jordanian IPO firms that are listed on the Amman Stock Exchange between 2000 and 2011. The findings of the current study present evidence that IPO firms in Jordan utilize real activities and accrual-based to manage reported income upward during the offering year. In particular, IPO firms in Jordan are found to inflate the reported net income during the offering year using accrual-based manipulation (discretionary accruals) and real activities-based manipulation (sales and discretionary expenses). This is in line with prior studies that find similar results on earnings manipulation around IPOs (Teoh et al., 1998; Roosenboom et al., 2003; Cormiera and Martinezb, 2006; Fan, 2007; Chahine et al. 2012; Bao et al. 2013; Wongsunwai, 2013; Alhadab et al., 2015; Alhadab et al., 2016; Gounopoulos and Pham 2016; Ertimur et al. 2017). This study therefore contributes to the knowledge by examining a sample that represents developing economies.

The structure of the current study is organized by the following. Section 2 provides literature review and hypothesis development. Section 3 presents research methods, sample construction, and variable measurement. Section 4 presents descriptive statistics and empirical findings. Robustness test is introduced in Section 5, while the conclusions are presented in Section 6.

\section{Literature Review}

\subsection{Earnings Management around IPOs}

The agency theory provides the theoretical background of the current study, which suggests that a higher level of information asymmetry leads to several agency conflicts e.g. moral hazard between managers (agent) and owners (principle). Information asymmetry is attributed to the lack of available public information about the firm when it was a private company (Aharony et al., 1993). Thus, managers of IPO firms can take advantage of this high level of information asymmetry and utilize earnings management to meet several incentives e.g. increase the offer price (Jensen and Meckling, 1976). In line with this, prior studies have found IPO firms use different techniques of earnings management to manage income upwards (Teoh et al., 1998; Roosenboom et al., 2003; Cormiera and Martinezb, 2006; Fan, 2007; Chahine et al. 2012; Bao et al. 2013; Wongsunwai, 2013; Alhadab et al., 2015; Alhadab et al., 2016; Gounopoulos and Pham 2016; Ertimur et al. 2017). Teoh et al. (1998) for example have examined whether US IPO firms utilize discretionary accruals around the offering year and found evidence on earnings manipulation. Teoh et al. (1998) have discussed several reasons that may lead managers of IPO firms to manipulate income and indicated that increasing the share prices and avoiding litigation risk are

\footnotetext{
${ }^{1}$ http://www.jordantimes.com/news/local/population-stands-around-95-million-including-29-million-guests
} 
considered as strong incentives of earnings management.

Despite this extensive evidence on earnings manipulation, few studies have argued that IPO firms do not manipulate their reported income during the IPO, and that the prior evidence on earnings manipulation around the offering year is attributed to measurement errors of earnings management proxies (e.g., Ball and Shivakumar, 2008; Cecchini et al., 2012). Other studies have pointed out that IPO firms do not manipulate reported income pre the IPO event since the monitoring by audit firms and outside investors is very high and, therefore, earnings management can be detected. More recently, Ertimur et al. (2017) have re-examined the association between earnings management and IPOs using a US sample. They have focused on quarterly data since this would help them to fully capture earnings management activities. Ertimur et al. (2017) have reported that IPO firms inflate their reported income, but just during the offering year. They have indicated that managers are restricted from selling their shares after the IPO until the lock-up period is expired and therefore, managers may manipulate reported income before the expiration date. In particular, Ertimur et al. (2017) have found IPO firms experience a higher level of discretionary accruals pre and during the expiration date's quarter.

A recent study by Gounopoulos and Pham (2016) have followed a different approach by examining the association between having a credit rating and earnings management for IPO firms. While this study confirms prior research on the presence of earnings management during the offering year, it provides unique evidence to the literature. In particular, Gounopoulos and Pham (2016) have found IPO firms which went public while having a credit rating report a lower level of real activities and accrual-based earnings management. Their results suggest that the agencies of credit rating play an effective role to discourage IPO firms from using earnings management. Gounopoulos and Pham (2016) have examined a very large sample of 2,602 IPOs over the period between 1991 and 2011.

Gao et al. (2017) have examined whether institutional investors in China take into consideration the level of real activities and accrual-based earnings management when they evaluate the IPO's offer price. They have found evidence that Chinese IPO firms use real activities and accruals accounting to increase their reported earnings pre the offering year. Gao et al. (2017) have found new evidence that institutional investors do consider earnings management by offering a lower price for the IPO firm that engaged in a higher level of real activities and discretionary accruals pre the IPO. They have examined a Chinese sample consists of 472 IPO firms covers the period from 2010 to 2012.

Further, Nam et al. (2014) have investigated whether the presence of venture capitalists is associated with earnings management during the IPO. They have examined a sample of 160 IPOs over the period 2001-2003 and found IPO firms utilize a higher level of earnings management when they backed by venture capitalists. However, they have found evidence that the presence of prestigious venture capitalists leads to a lower level of earnings management. In other words, prestigious venture capitalists do care about their reputation and therefore paly an effective monitoring role to prevent any earnings management activities undertaken by their backed IPO firms.

\subsection{Earnings Management Practices by Jordan Public Firms}

Several studies have found evidence that Jordanian public firms utilize different techniques of earnings management to manipulate income upwards. Abed at al. (2012) for example have studied the association between corporate governance mechanism and earnings management in Jordan. Based on a sample consists of 329 firm-year observations covers the period from 2006 to 2009, Abed at al. (2012) have found that the higher number of directors on the board the lower level of accrual-based earnings management. Their results suggest that public firms with a large board size are effectively monitored by the board and therefore these public firms have less flexibility to utilize earnings management. Further, Hamdan et al. (2013) have investigated whether the characteristics of audit committee impact accrual earnings management using a Jordanian sample consists of 50 industrial public firms. They have found evidence that some of the characteristics of audit committee lead to reduce the use of accrual earnings management.

Alzoubi (2016) in the meanwhile has examined the association between audit quality and earnings management. Using a sample of 86 Jordanian public firms over the period from 2007 to 2010, Alzoubi (2016) has found the quality of audit firms is associated with the use of accrual-based earnings management, suggesting that firms audited by high quality audit firms (Big 4) report a lower level of discretionary accruals. Alqatamin et al. (2017) have explored whether the personal characteristics of CEOs can impact earnings management based on a Jordanian sample of 201 public firms. They have found evidence that overconfidence of CEOs can lead to a higher level of earnings management. Alqatamin et al. (2017) also have found evidence that family firms in Jordan report a higher level of earnings management as compared to non-family firms. 
In summary, earnings management is widely practiced by Jordanian pubic firms. The regulatory environment of the Amman Stock Exchange as indicated before is not restricted as compared to other developed stock exchanges and, therefore, it is expected that public firms will utilize several techniques of earnings management to meet several incentives.

\subsection{Earnings Management around IPOs in Jordan}

Although prior studies have found evidence that Jordanian public firms utilize earnings management to meet several targets (Abed at al., 2012; Hamdan et al., 2013; Abu Jebril and Al.Thuneibat, 2016; Alzoubi, 2016; Alqatamin et al., 2017; Ibrahim and Al Awawdeh, 2017), no studies to date have examined whether IPO firms in Jordan utilize earnings management around the offering year. The IPO is very important change in the firms' life cycle and plays a major role to determine firms' future operations. However, it is well-documented that IPO firms manipulated the reported income during the offering year to meet several motives e.g. increase IPO price, increase the share price, avoiding the risk of litigation, etc (e.g. Teoh et al., 1998; Gramlich and Sorensen, 2004; Alhadab, 2016).

As discussed before, an IPO firm is a firm that switched from being a private firm with a higher level of information asymmetry to a public firm that have to meet several listing and disclosure requirements. To ensure decreasing information asymmetry before going public, developed stock exchanges require the IPO firms to meet very restricted requirements pre the IPO. For example, and as indicated by Alhadab et al. (2016), the Main market of the London Stock Exchange imposed very restricted requirements on IPO firms that consider going public on its exchange e.g., having previous earnings records, meeting a minimum market capitalization, complying with strong corporate governance standards, etc. All these restricted requirements would for sure lead to decrease information asymmetry in the capital market and, therefore, decrease managers' ability to inflate reported income around the offering year.

Unfortunately, the authorities in Jordan are unable to apply such restricted requirements on private Jordanian firms that considering going public on the ASE, notably the majority of public firms are small family business firms. With such case, it is therefore expected that IPO firms in Jordan will utilize several techniques to manage reported income upwards during the offering year. This study will focus on two techniques of earnings management; accrual-based and real activities-based earnings management. Hence, the main hypothesis of this study is as follow:

H1: IPO firms in Jordan report a higher level of accrual and/or real earnings management during the offering year.

\section{Research Method}

\subsection{Study Population and Sample}

The sample of this study includes all IPO events that took place in Jordan between 2000 and 2011. The sample starts in 2000 as this earliest date that IPOs data are available to the public by the ASE. The ending period for the sample is 2011 as after this date there is no any IPOs activities in the market. Following prior studies, the sample of this study excludes all financial and insurance IPO firms since the standards of financial reporting and disclosure system for these firms are different from other service and industrial firms (e.g. Chang et al. 2010; Lee and Masulis, 2011; Alhadab 2016b; Alhadab and Tahat, 2016). The Amman Stock Exchange (ASE) website is used to download all financial data about the IPOs sample. The annual reports are used to collect any missing financial variables (e.g. total assets, sales, etc) and data related to the audit firms (e.g. name of audit firms, audit tenure, etc). While data related to the IPOs e.g. the offer price, number of shares offered, name of underwriters and other related data are collected from annual reports of the ASE.

Further, and as a standard process of estimating earnings management for IPO firms, the analysis should be first started with estimating earnings management to all non-IPO public firms (the control sample) over the same sample period. Thus, all financial data for the control sample are collected from the ASE website as well. After completing the data collection process, which requires the IPO firm to have all necessary data for the analysis in order to be included into the sample, the final sample of this study consists of 41 IPO firms that listed on the ASE between 2000 and 2011.

\subsection{Measurement of Variables}

\subsubsection{Accrual Earnings Management}

Consistent with prior studies (e.g. Bao et al. 2013; Gounopoulos and Pham 2016; Ertimur et al. 2017) that examines earnings management around IPOs, discretionary accruals are employed by the current study as the 
main measure of accrual-based earnings management. For the estimation process, this study applies the corrected model of Jones (1991) as suggested by Dechow et al. (1995) to estimate normal accruals. Then, discretionary accruals are computed as the difference between actual total accruals and the estimated normal accruals. Following Alhadab 2015 and Alhadab et al. 2015, the normal accruals are first estimated for the control sample (all non-IPO firms). Then, the estimated coefficients are used to estimate normal accruals for the IPO firms. This approach is used to control for economics factors that may affect the estimation of discretionary accruals (Kasznik, 1999; Alhadab, 2016b). The following cross-sectional OLS regression is used to estimate normal accruals for the control sample (all non-IPO firms) for each industry-year category that has at least six observations (Rosner, 2003; Athanasakou et al., 2009; Alhadab et al., 2015).

$$
\frac{T_{i, t}}{\text { ASSETS }_{i, t-1}}=a_{0}+\beta_{1} \frac{1}{\text { ASSETS }_{i, t-1}}+\beta_{2} \frac{\Delta S A L E S_{i, t}}{\text { ASSETS }_{i, t-1}}+\beta_{3} \frac{\text { PPE }_{i, t}}{\text { ASSETS }_{i, t-1}}+\varepsilon
$$

Where TA is total accruals that is computed as earnings minus operating cash flows, ASSETS $_{t-1}$ is total assets at the beginning of the year, $\triangle S A L E S$ is the change in sales over two years, and PPE is the gross property, plant and equipment. To avoid Heteroscedasticity all variables are scaled by lagged total assets

Then, the estimated coefficients as computed in equation (1) are used to compute the normal accruals for the IPO firms in each industry and year as follows.

$$
N A_{i, t}=\hat{a}_{0}+\hat{\beta}_{1} \frac{1}{\text { ASSETS }_{i, t-1}}+\hat{\beta}_{2} \frac{\Delta S A L E S_{i, t}-\triangle \mathrm{REC}_{i, t}}{\text { ASSETS }_{i, t-1}}+\hat{\beta}_{3} \frac{\operatorname{PPE}_{i, t}}{\operatorname{ASSETS}_{i, t-1 t}}
$$

Where $\triangle R E C_{i, t}$ is the change in receivables over two years. Discretionary accruals $(D A)$ are computed as the difference between actual total accruals and the estimated normal accruals.

\subsubsection{Real Earnings Management}

Following Roychowdhury (2006), Gounopoulos and Pham (2016) and Ertimur et al. (2017), this study examines two widely used proxies of real earnings management activities; abnormal level of cash flows from operations $(A B N C F O)$ that result from sales-based manipulation and abnormal level of discretionary expenses (ABNDEXP) that result from cutting discretionary expenses. As discussed by Roychowdhury (2006) and Alhadab et al. 2016), the first activity is sales-based manipulation that aims to increase sales in the current period by offering more price discounts and/or more lenient credit terms. The second activity is used to increase reported income by reducing discretionary expenses (selling, research and development and advertising expenses). ${ }^{2}$

Similar to discretionary accrual estimation process, this study estimates first the normal level of real earnings management activities for the control sample (all non-IPO firms) using Roychowdhury (2006) models. Then, the estimated coefficients are used to estimate normal activities for the IPO firms. Hence, this study follows prior research (Gounopoulos and Pham 2016; Ertimur et al. 2017) and uses cross-sectional OLS regressions to estimate the normal activities for the control sample (all non-IPO firms) for each industry-year category that has at least six observations (Rosner, 2003; Athanasakou et al., 2009; Alhadab et al., 2015). The models are as follows.

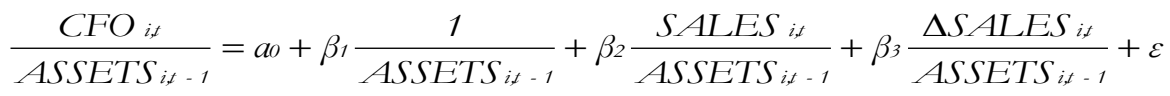

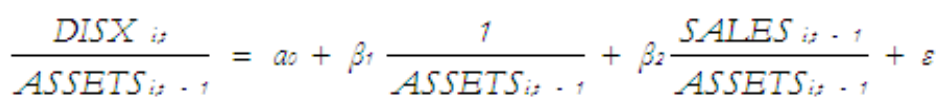

where $C F O_{i, t}$ is cash flows from operations, SALES ${ }_{i, t}$ is sales in the current year, and SALES $_{i, t-1}$ is sales in the previous year, $D I S X_{i t}$ is the sum of $\mathrm{R} \& \mathrm{D}, \mathrm{SG} \& \mathrm{~A}$, and advertising expenses in the current year. The estimated coefficients as computed in equations 3 and 4 are used to compute the normal activities of operating cash flows and discretionary expenses for the IPO firms in each industry and year. Then, the abnormal level of cash flows from operations is calculated as the actual level of operating cash flows minus the normal estimated level. While

\footnotetext{
${ }^{2}$ This study does not examine production costs-based manipulation since this activity is mainly used by manufacturing firms (Roychowdhury, 2006; Alhadab et al. 2015). The manufacturing firms represent very low percentage of the population of this sample.
} 
the abnormal discretionary expenses are computed as the difference between actual discretionary expenses and the normal estimated level.

To examine the overall effect of real earnings management, this study follows recent research (Cohen and Zarowin 2010; Chi et al. 2011; Alhadab et al. 2015) and computes an aggregated measure of real activities-based earnings management $(R E M)$; that is calculated as the sum of abnormal level of cash flows from operations and abnormal level of discretionary expenses. Both abnormal level of cash flows from operations and abnormal level of discretionary expenses are multiplied by minus on to have consistent interpretation in terms of income-increasing.

\subsection{Empirical Model}

To examine whether IPO firms in Jordan utilize accrual and real earnings management during the offering year, this study follows Ball and Shivakumar (2008) and uses an empirical model for a pooled sample of IPO firms (the IPO sample) and all non-IPO firms (the control sample) over the sample period. The model is as follows.

$$
\begin{aligned}
E M_{\mathrm{it}}=a_{0}+ & \beta_{1} I P O_{\mathrm{it}}+\beta_{2} S I Z E_{\mathrm{it}}+\beta_{3} B I G 4_{\mathrm{it}}+\beta_{4} R O A_{\mathrm{it}}+\beta_{5} \operatorname{LOSS}_{\mathrm{it}} \\
& +\beta_{6} \mathrm{LEV}_{\mathrm{it}}+\beta_{7} B M_{\mathrm{it}}+I N D+Y_{\text {ear }}+\varepsilon_{\mathrm{it}}
\end{aligned}
$$

The dependent variable is a proxy of the absolute values of real activities and accrual-based earnings management measures $(E M)$ as follows; discretionary accruals $(D A)$, abnormal level of cash flows from operations $(A B N C F O)$, abnormal level of discretionary expenses (ABNDEXP); and the aggregated measure of real activities-based earnings management $(R E M)$. The main explanatory variable of interest is the IPO dummy variable (IPO); which equals 1 if the firm is an IPO and zero otherwise. If the IPO firms report a higher level of real activities and discretionary accruals during the offering year, then it is expected to find a positive and significant coefficient on the IPO dummy (IPO).

The model also includes a set of control variables that impacts accrual and real earnings management. Starting with the size effect $(S I Z E)$, the model includes the natural logarithm of total assets as a proxy of firm size. Prior research has reported mixed evidence for the effect of size on earnings management. On the one hand, Jensen and Meckling (1976) have pointed out that large firms have many agency conflicts and complex operations that would motivate the use of earnings management. On the other hand, Meek et al. (2007) and Kohlbeck and Mayhew (2017) have indicated that large firms are expected to find it hard to manage earnings because they usually use very good accounting system and monitored by an efficient governance mechanism. Given this mixed evidence, no prediction is made on the association between size and earnings management.

The quality of audit firms is found to be a significant determinant of using both accrual and real earnings management. In particular, prior research has found e vinced that high quality audit firms play an effective role to constrain the use of accrual earnings management. But as a result for this monitoring on accruals manipulation, managers are found to switch to use more real earnings management (Cohen and Zarowin 2010; Chi et al. 2011; Alhadab 2016a). Thus, the model includes a control for audit quality (BIG4) that is a dummy variable equals 1 if the auditor from the big four audit firms and zero otherwise.

The model also controls for profitability, financial leverage and growth opportunities by adding return on assets $(R O A)$, a loss dummy (LOSS), financial leverage ratio ( $L E V)$, and book to market ratio $(B M)$. ROA is defined as net income divided by total assets, LOSS is a dummy variable equals 1 if the firm reports losses and zero otherwise, $L E V$ is calculated as total debt divided by total assets, and $B M$ is calculated as book value of equity divided by market value of equity. Similar to the size, mixed evidence is reported on the association between profitability, financial leverage, growth proxies and earnings management. This is due to the fact that these variables are highly correlated with earnings management measures, and the later are likely to be estimated with errors (e.g. Alhadab et al. 2016). Thus, no prediction is made on the direction of the relationships. Finally, controls for industry (IND) and time (Year) effects are added into the model.

\section{Findings}

\subsection{Descriptive Statistics}

Table 1 reports the descriptive statistics and shows that IPO firms report a higher level of real activities and discretionary accruals during the offering year. In particular, Table 1 shows the median values of $D A, A B N C F O$, $A B N D E X P$, and REM are 0.004, 0.024, 0.012, and 0.010, respectively. The median values of real and accrual earnings management proxies are greater than the mean values; which indicates these variable are negatively skewed. Table 1 also shows that just around ten percent of the IPO sample are audited by high quality audit firms 
(BIG4) and approximately 36 percent of the sample firms report losses (LOSS) during the IPO. Prior research finds that IPO firms audited by low quality audit firms report a higher level of earnings management (Chen et al. 2005).

Table 1. Descriptive statistics for IPOs sample over the period 2000-2011

\begin{tabular}{lccccc}
\hline & Mean & Median & S.D & Min & Max \\
\hline$D A$ & -0.038 & 0.004 & 0.272 & -1.328 & 0.337 \\
$A B N C F O$ & 0.006 & 0.024 & 0.165 & -0.452 & 0.337 \\
$A B N D E X P$ & -0.024 & 0.012 & 0.097 & -0.422 & 0.073 \\
$R E M$ & -0.018 & 0.010 & 0.211 & -0.656 & 0.410 \\
SIZE & 16.603 & 16.409 & 1.467 & 14.180 & 20.987 \\
BIG4 & 0.098 & 0.000 & 0.300 & 0.000 & 1.000 \\
ROA & -0.173 & 1.100 & 11.287 & -49.690 & 20.910 \\
LOSS & 0.366 & 0.000 & 0.488 & 0.000 & 1.000 \\
LEV & 0.087 & 0.025 & 0.129 & 0.000 & 0.475 \\
$B M$ & 0.747 & 0.445 & 0.783 & 0.004 & 3.134 \\
\hline$N$ & 41 & & & \\
\hline
\end{tabular}

This table presents descriptive statistics for the IPOs sample over the period from 2000 to 2011 . All variables are defined earlier in section 3 .

Table 2 presents the time distribution of IPO firms over the period from 2000 to 2011. Table 2 shows that years 2000 and 2003 experience the greatest number of IPOs with 14 IPOs each, while other years show similar IPOs frequency with a range from one IPO in both 2010 and 2011 to four IPOs in 2005. The dot-come bubble occurred in 2000 and therefore this may explain the increased IPOs around this period.

Table 2. Time distribution of for IPOs sample over the period 2000-2011

\begin{tabular}{lll}
\hline Year & Freq & \% \\
\hline 2000 & 14 & 34.15 \\
2003 & 14 & 34.15 \\
2004 & 2 & 4.88 \\
2005 & 4 & 9.76 \\
2008 & 3 & 7.32 \\
2009 & 2 & 4.88 \\
2010 & 1 & 2.44 \\
2011 & 1 & 2.44 \\
Total & $\mathbf{4 1}$ & $\mathbf{1 0 0}$ \\
\hline
\end{tabular}

This table presents the time distribution of for IPOs sample over the period 2000-2011.

Table 3 presents the industry distribution of IPO firms over the period from 2000 to 2011. Table 3 shows that services industry accounts for 17 percent of the sample IPOs, while the frequency of IPOs in other industries is within the range from 2.44 percent to 9.76 percent.

Table 3. Industry distribution of for IPOs sample over the period 2000-2011

\begin{tabular}{lccc}
\hline Industry & 2-digit SIC & Freq & \% \\
\hline Constructions & 11 & 2 & 4.88 \\
Food products & 12 & 5 & 12.2 \\
Mining & 13 & 4 & 9.76 \\
Paper and paper products & 14 & 1 & 2.44 \\
Chemicals products & 15 & 1 & 2.44 \\
Pharmaceutical & 16 & 1 & 2.44 \\
Electronic equipment & 17 & 1 & 2.44 \\
Hospitality & 21 & 5 & 12.2 \\
Healthcare & 22 & 3 & 7.32 \\
Education & 23 & 3 & 7.32 \\
Computer equipment & 24 & 4 & 9.76 \\
Services industry & 25 & 7 & 17.07 \\
Transportation & 27 & 1 & 2.44 \\
Media industry & 31 & 3 & 7.32 \\
\hline Total & & 41 & 100 \\
\hline
\end{tabular}

This table presents the Industry distribution of for IPOs sample over the period 2000-2011

Table 4 presents the correlation matrix for all variables included in the analysis. Starting with discretionary accruals, Table 4 shows that DA is positively correlated with ABNCFO and REM. This suggests that accrual and real earnings management are both complementary techniques used by IPO firms to manage reported earnings upwards. While for sales-based manipulation, Table 4 shows that ABNCFO is positively correlated with REM. 
In terms of discretionary expense-based manipulation, Table 4 shows evidence that ABNDEXP is positively correlated with REM. Table 4 also reports the correlation for the aggregated measure of real activities-based earnings management and shows that REM is positively correlated with financial leverage (LEV), suggesting that IPO firms with a higher debt ratio engage in a higher level of real earnings management.

Table 4. Correlations matrix for all variables included in the analysis

\begin{tabular}{|c|c|c|c|c|c|c|c|c|c|c|}
\hline & $D A$ & $A B N C F O$ & $A B N D E X P$ & $R E M$ & $S I Z E$ & BIG4 & $R O A$ & $L O S S$ & $L E V$ & $B M$ \\
\hline$D A$ & 1 & & & & & & & & & \\
\hline$A B N C F O$ & $0.654^{* * * *}$ & 1 & & & & & & & & \\
\hline$A B N D E X P$ & -0.0756 & 0.212 & 1 & & & & & & & \\
\hline$R E M$ & $0.482^{* *}$ & $0.889^{* * * *}$ & $0.635^{* * *}$ & 1 & & & & & & \\
\hline SIZE & 0.150 & 0.0579 & 0.211 & 0.144 & 1 & & & & & \\
\hline BIG4 & $0.347^{*}$ & 0.258 & 0.167 & 0.282 & 0.133 & 1 & & & & \\
\hline$R O A$ & 0.0340 & -0.0286 & -0.183 & -0.108 & 0.342 & -0.116 & 1 & & & \\
\hline LOSS & 0.181 & 0.126 & 0.284 & 0.232 & 0.0950 & 0.177 & $-0.603^{* * *}$ & 1 & & \\
\hline$L E V$ & 0.271 & 0.329 & 0.270 & $0.386^{*}$ & 0.138 & 0.325 & -0.140 & 0.0691 & 1 & \\
\hline$B M$ & $0.403^{*}$ & 0.240 & 0.120 & 0.246 & 0.0314 & 0.163 & -0.168 & 0.292 & $0.352^{*}$ & 1 \\
\hline
\end{tabular}

This table presents Pearson correlation matrix for all variables included in the analysis. Significant at: $* 10, * * 5$ and $* * * 1$ percent levels. All variables are defined earlier in section 3 .

\subsection{Empirical Results}

\subsubsection{Accrual Earnings Management around IPOs}

Table 5 reports the results whether IPO firms in Jordan use accrual earnings management to manage earnings upwards during the offering year. Column 1 of Table 5 reports the results and shows evidence on accrual-based manipulation. In particular, Column 1 of Table 5 shows the coefficient on IPO is positive (0.084) and statistically significant at one percent level. This evidence is consistent with the main hypothesis of this study that IPO firms in Jordan report a higher level of accrual earnings management during the offering year. Further, this evidence is consistent with prior studies that find IPO firms use accrual-based earnings management during the offering year to inflate reported earnings (Alhadab, 2015; Ertimur et al., 2017).

\subsubsection{Real Earnings Management around IPOs}

Columns 2, 3 and 4 of Table 5 present the results on real earnings management around IPOs. Column 2 of Table 5 reports the results on sales-based manipulation and shows that IPO firms manipulate their sales to inflate reported earnings. In particular, Column 2 of Table 5 shows the coefficient on IPO is positive (0.054) and statistically significant at five percent level. This evidence also confirms the main hypothesis of this study that IPO firms in Jordan report a higher level of real earnings management via sales-based manipulation during the IPO. Similar evidence is reported by prior research for sales based-manipulation using a de veloped context e.g. UK IPOs (Alhadab et al., 2015) and US IPOs (Wongsunwai, 2013).

Column 3 of Table 5 reports the results on discretionary-based manipulation and shows similar finding that IPO firms in Jordan cut their discretionary expenses to increase reported earnings. As can be seen from column 3 of Table 5 that the coefficient on IPO is positive $(0.028)$ and statistically significant at five percent level. This evidence also confirms the main hypothesis of this study that IPO firms in Jordan report a higher level of real earnings management via discretionary expenses-based manipulation during the offering year. Gounopoulos and Pham (2016) find IPO firms reduce their discretionary expenses to manage reported earnings.

The results on the association between the aggregated measure of real activities and IPOs are presented in column 4 of Table 5. The reported results show similar finding that IPO firms in Jordan report a higher level of real earnings management via the aggregated measure during the offering year. In particular, column 4 of Table 5 shows the coefficient on $I P O$ is positive (0.068) and statistically significant at five percent level. This evidence is also consistent the main hypothesis of this study that IPO firms in Jordan report a higher level of real earnings management during the IPO. Prior accounting research has found similar finding that IPO firms report a higher level of real earnings management via the aggregated measure during the IPO (e.g. Alhadab et al. 2016).

In summary, the results reported in Table 5 provide the first evidence to literature that IPO firms in Jordan manage their reported earnings during the offering year using both accrual and real earnings management. This evidence is also consistent with the main hypothesis of this study. Thus, using real activities and accrual-based earnings management to inflate reported income during the offering year is widely used practice not just in developed countries e.g. US and UK, but also in developing countries like Jordan. 
Table 5. The association between accrual and real earnings management and IPOs

\begin{tabular}{|c|c|c|c|c|}
\hline & $\begin{array}{c}\text { Column } 1 \\
D A\end{array}$ & $\begin{array}{l}\text { Column } 2 \\
A B N C F O\end{array}$ & $\begin{array}{c}\text { Column } 3 \\
A B N D E X P\end{array}$ & $\begin{array}{c}\text { Column } 4 \\
\text { REM }\end{array}$ \\
\hline Constant & $\begin{array}{c}0.075^{*} \\
(1.685)\end{array}$ & $\begin{array}{c}0.108^{*} \\
(1.680)\end{array}$ & $\begin{array}{c}0.098 * * * \\
(3.612)\end{array}$ & $\begin{array}{c}0.143 * * \\
(2.110)\end{array}$ \\
\hline IPO & $\begin{array}{c}0.084 * * * \\
(3.712)\end{array}$ & $\begin{array}{c}0.054 * * \\
(2.529)\end{array}$ & $\begin{array}{c}0.028 * * \\
(2.161)\end{array}$ & $\begin{array}{c}0.068 * * \\
(2.420)\end{array}$ \\
\hline SIZE & $\begin{array}{c}-0.002 \\
(-0.940)\end{array}$ & $\begin{array}{c}-0.004 \\
(-0.925)\end{array}$ & $\begin{array}{c}-0.003 * * \\
(-2.106)\end{array}$ & $\begin{array}{c}-0.005 \\
(-1.192)\end{array}$ \\
\hline BIG4 & $\begin{array}{c}0.002 \\
(0.189)\end{array}$ & $\begin{array}{c}-0.016 \\
(-1.352)\end{array}$ & $\begin{array}{c}0.005 \\
(0.853)\end{array}$ & $\begin{array}{c}-0.006 \\
(-0.489)\end{array}$ \\
\hline$R O A$ & $\begin{array}{c}0.001 \\
(0.846)\end{array}$ & $\begin{array}{c}0.001 \\
(1.071)\end{array}$ & $\begin{array}{c}0.000 \\
(1.343)\end{array}$ & $\begin{array}{c}0.001 \\
(1.056)\end{array}$ \\
\hline$L O S S$ & $\begin{array}{c}0.027 * * \\
(2.308)\end{array}$ & $\begin{array}{c}0.008 \\
(0.532)\end{array}$ & $\begin{array}{c}0.001 \\
(0.128)\end{array}$ & $\begin{array}{c}-0.003 \\
(-0.175)\end{array}$ \\
\hline$L E V$ & $\begin{array}{c}-0.028 \\
(-1.542)\end{array}$ & $\begin{array}{c}0.003 \\
(0.055)\end{array}$ & $\begin{array}{l}-0.020^{*} \\
(-1.843)\end{array}$ & $\begin{array}{c}-0.002 \\
(-0.033)\end{array}$ \\
\hline$B M$ & $\begin{array}{c}-0.001 \\
(-1.025)\end{array}$ & $\begin{array}{c}0.003 \\
(0.862)\end{array}$ & $\begin{array}{c}0.000 \\
(0.828)\end{array}$ & $\begin{array}{c}0.004 \\
(0.980)\end{array}$ \\
\hline Industry dummies & Yes & Yes & Yes & Yes \\
\hline Year dummies & Yes & Yes & Yes & Yes \\
\hline Total observations & 444 & 453 & 453 & 453 \\
\hline IPOs observations & 41 & 41 & 41 & 41 \\
\hline$R$-squared & 0.248 & 0.148 & 0.269 & 0.158 \\
\hline Adj.R-squared & 0.184 & 0.077 & 0.207 & 0.087 \\
\hline
\end{tabular}

This table reports the results whether IPO firms in Jordan use accrual and real earnings management to manage reported earnings during the offering year. Discretionary accruals are estimated using the corrected version of Jones (1991) model as suggested by Dechow et al. (1995). Real activities measures (ABNCFO and ABNDEXP) are estimated using Roychowdhury (2006) model. Industry and year effects are controlled across all models. ***, ** and *, represent significance at the one percent, five percent, and ten percent levels, respectively. T-statistics appeared in parentheses and based on robust standard errors. All variables are defined earlier in section 3 .

\section{Robustness Test}

For robustness this study follows Ball and Shivakumar (2008) and estimates discretionary accruals using the piecewise linear variant of the Jones (1991) model. The estimation approach of Ball and Shivakumar (2008) is similar to the estimation process of discretionary accruals; which is explained in Section 3.2.1. The one main difference is the variables that included into the model. Thus, the following cross-sectional OLS regression as suggested by Ball and Shivakumar (2008) is used to estimate normal accruals for all non-IPO firms for each industry-year category that has at least six observations (Rosner, 2003; Athanasakou et al., 2009; Alhadab et al., 2015).

$$
T A_{i, t}=\alpha_{0}+\beta_{1} \Delta S A L E S_{i, t}+\beta_{2} P P E_{i, t}+\beta_{3} C F O_{i, t}+\beta_{4} D_{C F O}+\beta_{5} D C F O_{i, t} * C F O_{i, t}+\varepsilon_{i, t}
$$

Where $T A$ is total accruals computed as earnings minus operating cash flows, $\triangle S A L E S$ is the change in sales over two years, $P P E$ is the gross value of property, plant and equipment, $C F O_{i, t}$ is operating cash flows, $D C F O_{i, t}$ is a dummy variable that equals 1 if firms report negative operating cash flows and zero otherwise. All variables are divided by lagged total assets to avoid Heteroscedasticity.

The estimated coefficients as computed in equation (6) are used to compute the normal accruals for IPO firms in each industry and year as follows.

$$
N A_{i, t}=\hat{\alpha}_{0}+\hat{\beta}_{1} \Delta S A L E S_{i, t}+\hat{\beta}_{2} P P E_{i, t}+\hat{\beta}_{3} C F O_{i, t}+\hat{\beta}_{4} D C F O_{i, t}+\hat{\beta}_{5} D C F O_{i, t} * C F O_{i, t}
$$

Discretionary accruals $(D A)$ are computed as the difference between actual total accruals and the estimated level of normal accruals.

Table I in the Appendix presents the result on the association between accrual earnings management that is estimated using the model of Ball and Shivakumar (2008) and IPOs. Table I in the Appendix reports similar evidence to the results reported in Table 5 that IPO firms in Jordan utilize accrual earnings management during the offering year to manipulate reported income upwards. In particular, Table I in the Appendix shows that the coefficient on IPO is positive (0.048) and statistically significant at one percent level. Thus, the findings of this study are robust using several models to estimate discretionary accruals. 


\section{Conclusions}

This study examines whether IPO firms in Jordan use real activities and accrual-based earnings management to manipulate income during the offering year. Based on a Jordanian sample of 41 IPOs that took place between 2000 and 2011, the findings of this study provide the first evidence to the literature that IPO firms in Jordan utilize real activities and accrual earnings management to inflate reported income during the offering year. In particular, the findings of this study show that Jordanian IPO firms report during the offering year a higher level of accruals-based, sales-based, discretionary expenses-based, and the aggregated measure of real activities-based earnings management.

This study contributes to the knowledge through several aspects. First, it provides new evidence on earnings management based on a developing IPOs context. Prior research has mainly focused on earnings management around IPOs in developed countries e.g. UK and US. Hence, the findings of current study can be generalized to other developing countries that have stock exchanges with similar characteristics to the Amman Stock Exchange. Second, this study sheds more light on earnings management activities by IPO firms in Jordan. In particular, the findings show that both accrual and real earnings management are complementary used to manipulate income in Jordan. Prior research has extensively examined accrual earnings management in Jordan (e.g. Abu Jebril and Al.Thuneibat, 2016; Alzoubi, 2016; Alqatamin et al., 2017; Ibrahim and Al Awawdeh, 2017), but just very few research has explored real activities. Third, this study provides a new avenue for future research in Jordan to explore further topics related to IPOs, a research area that has not received much attention by prior research as compared to other developed context.

The findings of this study also present very important implications for policy makers, regulators, and other authorities in Jordan about the presence of earnings management around IPOs. It is well-researched that accrual and real earnings management during the IPO can lead to sever negative consequences not just for the IPO firm, but also for its stakeholders. Alhadab et al. (2015) find a positive association between bankruptcy risk and the level of earnings management for a sample of British IPOs. Thus, the Amman Stock Exchange and the Jordan Securities Commission should work together to reform the regulations that related to IPO firms. For example, these reforms should consider imposing new requirements on IPO firms before they can go public that include but not limited to a previous earnings record, complying with an effective corporate governance mechanism, audited by high quality audit firms, providing full disclosure on their operations. Imposing such restricted requirements would for sure prevent the use of earnings management and protect firm's stakeholders.

\section{Acknowledgment}

This research project received financial supported from Al al-Bayt University/ Decision 2016/2015/5. Dr. Mohammad Alhadab is grateful for the financial support for this project that received from Al al-Bayt University/Deanship of Academic Research. Also, Dr. Alhadab is grateful for Ayat Al-Bairuti and Alaa Suliaman for their assistance in collecting the IPOs data.

\section{References}

Abed, S., Al-Attar, A., \& Suwaidan, M. (2012). Corporate governance and earnings management: Jordanian evidence. International Business Research, 5(1), 216-221.

Abu Jebril, A. Y., \& Al.Thuneibat, A. (2016). The impact of internal audit on earnings management in the industrial companies listed in Amman Stock Exchange. Jordan Journal of Business Administration, 12(4), 789-811. https://doi.org/10.12816/0034969

Aharony, J., Lin, C. J., \& Loeb, M. P. (1993). Initial Public Offerings, accounting choices, and earnings management. Contemporary Accounting Research, 10(1), 61-81. https://doi.org/10.1111/j.1911-3846.1993.tb00382.x

Alhadab, M. (2015). Do nonaudit fees associate with accrual earnings management during the IPO. Corporate Ownership and Control, 12 (3), 441-453. https://doi.org/10.22495/cocv12i3c4p5

Alhadab, M. (2016a). IPO underpricing and audit quality: Evidence from the Alternative Investment Market in the UK. Corporate Board: Role, Duties and Composition, 12(2), 104-110.

Alhadab, M. (2016b). Auditor report and earnings management: Evidence from FTSE 350 companies in the UK. Risk Governance and Control: Financial Markets \& Institutions, 6(4), 334-344. https://doi.org/10.22495/rgcv6i4c2art11

Alhadab, M., \& Tahat, Y. (2016). The value relevance of unrealized gains and losses around the financial credit crisis: Evidence from the UK. Corporate Ownership \& Control, 14(1), 351-359. 
https://doi.org/10.22495/cocv14i1c2p7

Alhadab, M., Clacher, I., \& Keasey, K. (2015). Real and accrual earnings management and IPO failure risk. Accounting and Business Research, 45(1), 55-92. https://doi.org/10.1080/00014788.2014.969187

Alhadab, M., Clacher, I., \& Keasey, K. (2016). Acomparative analysis of real and accrual earnings management around initial public offerings under different regulatory environments. Journal of Business Finance and Accounting, 43(7-8), 849-871. https://doi.org/10.1111/jbfa.12201

Alqatamin, R. M., Aribi, Z. A., \& Arun, T. (2017). The effect of the CEO's characteristics on EM: Evidence from Jordan. International Journal of Accounting and Information Management, 25(3), 356-375. https://doi.org/10.1108/IJAIM-10-2016-0099

Alzoubi, E. S. S. (2016). Disclosure quality and earnings management: Evidence from Jordan. Accounting Research Journal, 29(4), 429-456. https://doi.org/10.1108/ARJ-04-2014-0041

Athanasakou, V. E., Strong, N. C., \& Walker, M. (2009). Earnings management or forecast guidance to meet analyst expectations? Accounting and Business Research, 39(1), 3-35. https://doi.org/10.1080/00014788.2009.9663347

Bao, B. H., Chung, R., Niu, Y., \& Wei, S. (2013). Real and accrual earnings management around IPOs: US evidence. Corporate Ownership \& Control, 10(3), 76-94. https://doi.org/10.22495/cocv10i3art7

Brau, J. C., \& Fawcett, S. E. (2006). Initial Public Offerings: An analysis of theory and practice. The Journal of Finance, 61(1), 399-436. https://doi.org/10.1111/j.1540-6261.2006.00840.x

Cecchini, M., Jackson, S., \& Liu, X. (2012). Do Initial Public Offering firms manage accruals? Evidence from individual accounts. Review of Accounting Studies, 17(1), 22-40. https://doi.org/10.1007/s11142-011-9160-9

Chahine, S., Arthurs, J. D., Filatotchev, I., \& Hoskisson, R. E. (2012). The effects of venture capital syndicate diversity on earnings management and performance of IPOs in the US and UK: An institutional perspective. Journal of Corporate Finance, 18(1), 179-192. https://doi.org/10.1016/j.jcorpfin.2011.11.007

Chang, S. C., Chung, T. Y., \& Lin, W. C. (2010). Underwriter reputation, earnings management and the long-run performance of Initial Public Offerings. Accounting \& Finance, 50, 53-78. https://doi.org/10.1111/j.1467-629X.2009.00329.x

Chen, K. Y., Lin, K. L., \& Zhou, J. (2005). Audit quality and earnings management for Taiwan IPO firms. Managerial Auditing Journal, 20, 86-104. https://doi.org/10.1108/02686900510570722

Chi, W., Lisic, L. L., \& Pevzner, M. (2011). Is enhanced audit quality associated with greater real earnings management? Accounting Horizons, 25(2), 315-335. https://doi.org/10.2308/acch-10025

Cohen, D. A., \& Zarowin, P. (2010). Accrual-based and real earnings management activities around Seasoned Equity Offerings. Journal of Accounting and Economics, 50(1), 2-19. https://doi.org/10.1016/j.jacceco.2010.01.002

Cormier, D., \& Martinez, A. (2006). The association between management earnings forecasts, earnings management, and stock market valuation: Evidence from French IPOs. The International Journal of Accounting, 41(3), 209-236. https://doi.org/10.1016/j.intacc.2006.07.004

Dechow, P. M., Sloan, R. G., \& Sweeney, A. P. (1995). Detecting earnings management. The Accounting Review, 70(2), 193-225.

Ertimur, Y., Sletten, E., Sunder, J., \& Weber, J. (2017). When and why do IPO firms manage earnings? Available at SSRN: https://ssrn.com/abstract=2704621

Fan, Q. (2007). Earnings Management and Ownership Retention for Initial Public Offering Firms: Theory and Evidence. The Accounting Review, 82(1), 27-64. https://doi.org/10.2308/accr.2007.82.1.27

Gao, S., Meng, Q., Chan, K. C., \& Wu, W. (2017). Earnings management before IPOs: Are institutional investors misled? Journal of Empirical Finance, 42, 90-108. https://doi.org/10.1016/j.jempfin.2017.02.003

Gounopoulos, D., \& Pham, H. (2016). Credit Rating Impact on Earnings Management around Initial Public Offerings. Journal of Business Finance and Accounting, 44(1-2), 154-1965. https://doi.org/10.1111/jbfa.12228

Gramlich, J. D., \& Sorensen, O. (2004). Voluntary management earnings forecasts and discretionary accruals: Evidence from Danish IPOs. European Accounting Review, 13(2), 235-259. https://doi.org/10.1080/0963818042000203338 
Hamdan, A. M., Mushtaha, M. S., \& Al-Sartawi, A. M. (2013). The audit committee characteristics and earnings quality: Evidence from Jordan. Australasian Accounting, Business and Finance Journal, 7(4), 51-80. https://doi.org/10.14453/aabfj.v7i4.5

Ibrahim, A., \& Al Awawdeh, H. (2017). Earnings management and its impact on accounting earnings quality Experimental study on the Jordanian industrial public shareholding companies. Jordan Journal of Business Administration, 13(2), 161-179.

Jensen, M. C., \& Meckling, W. H. (1976). Theory of the firm: Managerial behavior, agency costs and ownership structure. Journal of Financial Economics, 3(4), 305-360. https://doi.org/10.1016/0304-405X(76)90026-X

JONES, J. J. (1991). Earnings management during import relief investigations. Journal of Accounting Research, 29, 193-228. https://doi.org/10.2307/2491047

Kasznik, R. (1999). On the association between voluntary disclosure and earnings management. Journal of Accounting Research, 37(1), 57-81. https://doi.org/10.2307/2491396

Kohlbeck, M., \& Mayhew, B. W. (2017). Are related party transactions red flags? Contemporary Accounting Research, 34(2), 900-928. https://doi.org/10.1111/1911-3846.12296

Lee, G., \& Masulis, R. W. (2011). Do more reputable financial institutions reduce earnings management by IPO Issuers? Journal of Corporate Finance, 17, 982-1000. https://doi.org/10.1016/j.jcorpfin.2011.04.012

Meek, G. K., Rao, R. P., \& Skousen, C. J. (2007). Evidence on factors affecting the relationship between CEO stock option compensation and earnings management. Review of Accounting and Finance, 6(3), 304-323. https://doi.org/10.1108/14757700710778036

Nam, D. I., Park, H. D., \& Arthurs, J. D. (2014). Looking attractive until you sell: Earnings management, lockup expiration, and venture capitalists. Journal of Management Studies, 51, 1286-1310. https://doi.org/10.1111/joms.12093

Roosenboom, P., van der Goot, T., \& Mertens, G. (2003). Earnings management and Initial Public Offerings: Evidence from the Netherlands. The International Journal of Accounting, 38(3), 243-266. https://doi.org/10.1016/S0020-7063(03)00048-7

Rosner, R. L. (2003). Earnings manipulation in failing firms. Contemporary Accounting Research, 20(2), 361-408. https://doi.org/10.1506/8EVN-9KRB-3AE4-EE81

Roychowdhury, S. (2006). Earnings management through real activities manipulation. Journal of Accounting and Economics, 42(3), 335-370. https://doi.org/10.1016/j.jacceco.2006.01.002

Teoh, S. H., Welch, I., \& Wong, T. J. (1998). Earnings management and the long-run market performance of Initial Public Offerings. The Journal of Finance, 53(6), 1935-1974. https://doi.org/10.1111/0022-1082.00079

Wongsunwai, W. (2013). The effect of external monitoring on accrual-based and real earnings management: Evidence from venture-backed Initial Public Offerings. Contemporary Accounting Research, 30(1), 296-324. https://doi.org/10.1111/j.1911-3846.2011.01155.x 


\section{The Appendix}

Table I. Re-examination of the association between accrual earnings management and IPOs

\begin{tabular}{|c|c|}
\hline DEPENDENT VARIABLE & $D A$ \\
\hline Constant & $\begin{array}{l}0.085 * * \\
(2.033)\end{array}$ \\
\hline$I P O$ & $\begin{array}{c}0.048^{* * *} \\
(3.940)\end{array}$ \\
\hline SIZE & $\begin{array}{c}-0.003 \\
(-1.131)\end{array}$ \\
\hline BIG4 & $\begin{array}{c}0.001 \\
(0.067)\end{array}$ \\
\hline$R O A$ & $\begin{array}{c}0.001 \\
(0.623)\end{array}$ \\
\hline LOSS & $\begin{array}{l}0.020^{*} \\
(1.752)\end{array}$ \\
\hline$L E V$ & $\begin{array}{c}-0.037 * * * \\
(-2.626)\end{array}$ \\
\hline$B M$ & $\begin{array}{c}-0.001 \\
(-1.527)\end{array}$ \\
\hline Industry dummies & Yes \\
\hline Year dummies & Yes \\
\hline Total firms & 444 \\
\hline IPOs firms & 41 \\
\hline$R$-squared & 0.211 \\
\hline Adj. R-squared & 0.143 \\
\hline
\end{tabular}

\section{Copyrights}

Copyright for this article is retained by the author(s), with first publication rights granted to the journal.

This is an open-access article distributed under the terms and conditions of the Creative Commons Attribution license (http://creativecommons.org/licenses/by/4.0/). 